\title{
ПРОЛАЗНОСТ И МЕТОДОЛОШКО ФИКСИРАҢЕ ДРУШТВЕНЕ СТВАРНОСТИ: СНИМАК КАО ПОДАТАК ИНТЕРПРЕТАТИВНЕ СОЦИОЛОГИЈЕ
}

\begin{abstract}
Фернан Леже (Fernand Léger), француски сликар и режисер, сањао је о колосалном филму који ће тачно двадесет и четири сата снимати живот једног мушкарца и једне жене; њихов рад, њихово ћутање, њихову интимност. Ништа се не би изоставило, а двоје протагониста не би знали да је камера присутна. Леже је био свестан да би слике које је замислио морале садржати шокантне призоре, јер приказују обично скривени вртлог сировог постојања. „Мислим“, приметио је, „да би то било толико ужасно, да би људи престрашено бежали и звали упомоћ, као да их је задесила катастрофа светских размера““”
\end{abstract}

Предговор из 2007. године

Текст који следи је први пут објављен пре двадесет година. Текст скреће пажњу на централни аспект квалитета процеса језичке интеракције, али будући да је првобитно објављен на месту где је лако могао промаћи пажњи заинтересованих за анализу разговора/конверзације (Konversationsanalyse), издавачи и аутор су дошли на идеју да га поново укључе у ово издање 4 како би га вратили у контекст живе расправе, јер и текстови имају своју пролазност.

У тексту се развија аргумент да се проналаском и ширењем аудиовизуелних технологија снимања омогућавају потпуно нови начини приступања пролазним процесима друштвене, језичке и нејезичке интеракције. Међутим, епистемолошки статус и методолошке могућности и ризици тих начина чувања записа су за друштвене науке и даље у великој мери нејасни, будући да њиховом целокупном методологијом доминира логика реконструкцијских приступа. Развој анализе разговора који је започео 60-их година XX века и његово уп-

\footnotetext{
${ }^{1}$ joerg.bergmann@uni-bielefeld.de

2 Jörg R. Bergmann (1985) „Flüchtigkeit und methodische Fixierung sozialer Wirklichkeit. Aufzeichnung als Daten der interpretativen Soziologie“, in: W. Bonß und H. Hartmann (Hrsg.) Entzauberte Wissenschaft: Zur Relativität und Geltung soziologischer Forschung (Sonderband 3 der Zeitschrift „Soziale Welt“), Göttingen: Otto Schwarz: 299-320. Захваљујем Петеру Гросу (Peter Gross) и Волфгангу Бонсу (Wolfgang Bonß) на разговорима, стрепљењу и дозираном нестрпљењу.

${ }^{3}$ Kracauer 1971: 106.

${ }^{4}$ Heiko Hausendorf (Hrsg.) (2007) Gespräch als Prozess: Linguistische Aspekte der Zeitlichkeit verbaler Interaktion, Tübingen: Gunter Narr Verlag.
} 
орно инсистирање на “natural data” („природним подацима“) може се, такође, тумачити као почетак иницијално несхваћене методолошке историје рефлексије - историје рефлексије која се у случају анализе конверзације до сада парадоксално појављује у облику често критикованог „емпиријског“ става. Свако ко инсистира на томе да се као емпиријски материјал могу дозволити само документи догађаја, лако бива осумњичен за “tape fetishism” (,фетишизирање снимка на траци“) или за носталгију за аутентичношћу (Ashmore et al. 2004). Међутим, оригинални мотив за ову методолошку одлуку није наивно веровање у природно „дато“ (= подаци), већ деконструктивистички маневар етнометодологије за растварање „датог“ у процесима његове локалне, ситуационе производње. А кључна карактеристика тако конципиране „стварности извршења“ (,Vollzugswirklichkeit“") јесте њен процесни карактер.

У овом се тренутку јавља дилема која је у овом тексту дата само у назнакама. С једне стране, као што нас је учио још Дилтај (Dilthey 1957: 317), протеривање пролазног објекта важан је предуслов за његову интерпретацију:

„Али и најнапетија пажња може само у том случају да постане методичан, систематичан процес у коме се постиже степен објективности и који се може контролисати, ако је животни израз фиксиран и ако самим тим увек наново можемо да му се вратимо.“5

С друге стране, механичка или накнадно писана „фиксација“ природно уклања пролазност и самим тим кључни елемент сваког израза живота. Уметност интерпретације се мора састојати управо од тога - да из фиксираног израза живота у први план врати протерану процесуалност. То значи да анализа конверзације не сме постати анализа транскрипта, већ је важно учинити евидентним како се образац, који треба идентификовати у транскрипту, развија кроз време у инкременталном процесу разговора. Међутим, може се приметити да циљ, да се процесни квалитет живог друштвеног догађаја истрошеног у транскрипту поново анализира, нестаје чим неко испред себе има писани запис. У том смислу, овај есеј треба схватити као мали обележивач који отвара рор-ир прозор на свакој страници овог издања као подсетник пролазности својствене разговору као процесу.

\section{I}

Откако је низ „интерпретативних“ истраживачких приступа почео да пушта корене у социологији немачког говорног подручја средином седамдесетих година, примећују се промене у изгледу, стилу и пракси емпиријских

\footnotetext{
${ }^{5}$ Вилхелм, Дилтај (1973) „Настанак херменеутике“, Поља 171: 7-10; стр. 7, с немачког превео Томислав Бекић. Упоредити са преводом Зорана Ђинђића: „Али и најнапрегнутија пажња може само онда тај поступак уздићи до вештине у којој се достиже степен објективности који се може контролисати, уколико су испољавања живота фиксирана и тако им се увек можемо да вратимо“ („Настанак херменеутике“ (94-118) из: Вилхелм Дилтај, Засниваюа духовних наука, Београд: БИГЗ, 1980, стр. 96).
} 
друштвених истраживања. Истраживачи који се отисну на тај пут више нису само заинтересовани за проналажење саговорника за интервјуе по унапред формулисаном упитнику, већ - често са ентузијазмом орнитолога-аматера трагају за искреним и наизглед изузетно баналним свакодневним разговорима како би их снимили. Студенти се више не муче само са проблемима кодирања, анализе узорка и конструкције скала у емпиријској пракси, већ све чешће проводе дане, чак и читаве седмице, до танчина транскрибујући један једини снимљени разговор. И свако ко данас пролази кроз социолошки институт може врло вероватно очекивати да неке од радних група које седе испред монитора нису заузете статистичком анализом података, већ прегледавају видео записе процеса друштвене интеракције који се готово бесконачно понављају на екранy.

Готово се чини као да су нови истраживачи интерпретативне социологије озбиљно кренули у остваривање Лежеовог сна на свој начин. Ниједан од њих још увек није успео да непрекидно и непримећено сликом и звуком забележи живот неког пара или породице током целог дана: још увек су само њихове колеге из области социологије они који ужаснуто беже и уочавају катастрофу; међутим, не може се превидети чињеница да се истраживачи у интерпретативној социологији у својој пракси прилично приближавају Лежеовом сну. Звучни и сликовни записи интерактивних процеса су предмет њиховог интересовања и ниједан догађај није превише баналан, ниједна радња превише интимна да им се не чини вредном снимања.

Данас се у интерпретативним друштвеним истраживањима - у оквиру свих школа, смерова и приступа - подразумева употреба аудиовизуелних уређаја за снимање и репродукцију како би се забележили, сачували и обрадили друштвени феномени и урадиле транскрипције тих снимака. Само то не мора да буде значајно. Нисмо ли се навикли да употребу диктафона, електричних писаћих машина и фотокопир машина узимамо здраво за готово, без да ови технички ресурси у социологији доведу до посебних промена или преиспитивања методологије ${ }^{6}$ Треба ли уређајима за аудиовизуелну репродукцију у истраживачкој пракси интерпретативних приступа доделити другачији статус од статуса техничких помоћних уређаја, који су прилично згодни јер олакшавају рад, али којих би се - ако би било потребно - могли одрећи у било ком тренутку?

Узмимо пример: анализа разговора/конверзације која је потекла као независно поље истраживања из етнометодологије. Од суштинског значаја за њен развој раних 1960-их били су радови Харвија Сакса (Sacks) и Емануела Шеглофа (Schegloff) о обрасцима друштвеног повезивања и категоризације, као и о механизмима секвенцирања друштвене интеракције. За стил овог рада било је карактеристично да се анализа стриктно заснива на магнетофонским снимцима спонтаних, односно отворених разговора (телефонски позиви грађана пси-

\footnotetext{
${ }^{6}$ Сматрам истинским недостатком то што до сада није истражено какав ефекат има фотокопир апарат на стил научног рада. Упоредити као експеримент: Giersch 1983.
} 
хијатријском саветовалишту или полицији). ${ }^{7}$ Измишљени примери реченица (на пример у теорији говорних чинова) или ретроспективни описи разговора (попут оних које је Гофман [Goffman] често користио) нису били употребљени као почетни материјал за анализу или су дозвољавани само у изузетним случајевима. До данас је методолошко ограничење заснивања истраживања на аудиовизуелним снимцима стварних процеса интеракције остало централни елемент у истраживачкој логици анализе конверзација. ${ }^{8}$

Нема разлике ни код једног другачијег интерпретативног приступа истраживању, објективне херменеутике. Њени представници посебно наглашавају методолошки захтев да израда протокола посматрања, који у овом истраживачком приступу служе као полазни материјал за интерпретативни рад који објашњава значења и реконструише случај, „буде што детаљнија и што је могуће ближа реалности, односно бар на нивоу добрих магнетофонских записа“ (Oevermann et al. 1979: 428). А за методу наративних интервјуа, која је последњих година пронашла бројне следбенике, посебно у биографским истраживањима, њен аутор језгровито постулира: „Наравно, квалитет таквих наративних интервјуа може да се у довољној мери и адекватно вреднује само ако су снимљени на траци“ (Schütze 1977: 10).

Једно је сигурно: уређаји за снимање неопходан су предуслов за новије интерпретативне приступе истраживању. Али зашто? Које нове могућности за социолошко сазнање отварају уређаји за аудиовизуелну репродукцију? И на који начин се природа предмета социолошког истраживања мења употребом ових уређаја?

Пре свега, мора се схватити да употреба уређаја за аудиовизуелну репродукцију у искуственим социолошким истраживањима сама по себи не представља револуционарну иновацију. Лингвисти и антрополози су за своје истраживачке циљеве користили акустичне и кинематографске снимке већ крајем прошлог века, само неколико година након што су успостављене њихове техничке основе. Наравно, они су играли само споредну улогу у даљој историји емпиријских друштвених истраживања у поређењу са другим методолошким ресурсима. Технике снимања користиле су се специјализовано, на пример, у развојној психологији и психологији изражавања, што се касније стопило са струјом истраживања невербалне комуникације. У антропологији су се рано развили различити жанровски облици етнографског филма који су имали за циљ да документују и реконструишу стране културе којима прети нестајање.

\footnotetext{
${ }^{7}$ Sacks 1972. и Schegloff 1968, садрже сажетак дисертација оба ова аутора које су завршене 1966. односно 1967.

${ }^{8}$ Преглед етнометодолошке конверзационе анализе са кратким приказом основних методолошких принципа може се наћи у: Bergmann 1981.
} 
И у социологији су се с времена на време јављали аутори који су се - углавном само експериментално - поигравали употребом филмских документараца о понашању. ${ }^{9}$ Међутим, то не мења чињеницу да осим у неколико покушаја употребе фотографија и документарних филмова у сврху социографских техника или друштвено-критичких медија, уређаји за аудиовизуелну репродукцију нису имали никакав значај као методолошки ресурси у социологији до 1960-их. ${ }^{10}$

Рани аудиовизуелни документарни филмови о понашању нису имали много везе са Лежеовим сном. Понекад су настајали у лабораторији у експериментално контролисаним условима, понекад су се ограничавали на „занимљиве“ или - као у случају хумане екологије - на теоретске феномене који су сами по себи изоловани. Често су снимци, такође накнадно монтирани према научним критеријумима класификације или, зарад естетских или образовних разлога, склапани у документарац са заплетом сличним играном филму. Очигледно, друштвени научници нису знали шта да раде са „голим“ аудиовизуеним репродуковањем тривијалних друштвених појава. Тек су уз „облачење“ у контролисане продукцијске услове, теоретско покриће и функционално обликовање конзервиране слике и звуци стекли своје научно достојанство.

У том контексту, јасно се истиче специфична и нова карактеристика интерпретативне истраживачке праксе: управо сирови, безинтересни, ни нумерички ни естетски трансформисани, сликовни и звучни запис свакодневних процеса интеракције чини примарни истраживачки материјал. Ово наивно регистративно руковање техникама аудиовизуелне репродукције никако није било подразумевано, већ је значило одрицање од познате теоријски посредоване селекције и креативне трансформације медијског објекта. Како је дошло до овог наивног регистративног посматрања и праксе снимања у интерпретативним социолошким истраживањима последњих година?

Пре свега, мора се узети у обзир могућност да је појава интересовања за сирове, необликоване документарне материјале повезана са ширим технолошким развојем уређаја за репродукцију. У сваком случају, упадљиво је да су почеци интерпретативних истраживачких приступа настали у време када су, због индустрије забаве и канцеларијске опреме са преносним касетофонима и видео рекордерима први пут на тржиште стигли згодни, неупадљиви и издржљиви уређаји за снимање и репродукцију на батерије који су били још и приступачни. Брзим ширењем ових уређаја, непосредно - и неупадљиво - бележење људског понашања у до тада невиђеној мери постала је рутинска ствар. Чињеница

\footnotetext{
${ }^{9}$ На пример, Кули са својим реторичким питањем: „Шта може бити прецизније од филма као записа видљивог понашања?“ (Cooley 1969: 314); или Гајгер, који би за свој аутосоциографски експеримент о друштвеном свету савремених људи најрадије користио „апарат за звучни филм“ (Geiger 1960: 59).

${ }^{10}$ Радови о историји техника аудиовизуелне репродукције у друштвеним наукама могу се наћи у антологији визуелне антропологије: Hockings 1975; у изврсном каталогу етнографског филма: Friedrich et al. 1984; у свесци на тему „Фотографија у друштвеним наукама“ (Wagner 1979) или у посебном издању часописа Sociological Methods \& Research о снимцима слике и звука у истраживању интеракције који је уредио Гримшо (Grimshaw 1982).
} 
да је почетком седамдесетих година амерички председник у то време све разговоре који су се одвијали у његовој канцеларији тајно снимао (о шта се касније „спотакао“) можда је најпознатији пример регистративног менталитета који се развио на овај начин. ${ }^{11}$ Тешко се могло избећи да се експерименти са овим новим техникама снимања изводе и у научној области, укључујући и емпиријска социолошка истраживања. Ови покушаји - на пример у случају развоја анализе разговора - потпомогнути су чињеницом да су неки социолози успели да добију приступ касетама на које су рутински снимани сви долазни телефонски позиви полицијским станицама или разним саветовалиштима.

Али без обзира на то колико су нови медији за репродукцију били важни за растуће интересовање за директним, неосмишљеним документарцима о понашању, свој значај могли су стећи само у концептуалном референтном оквиру који је претходно био успостављен радовима Зимла, Вебера и Шица и њиховим емпиријским пројекцијама код Гофмана и Гарфинкела. Само уколико је „свакодневни живот“ већ био откривен у теорији, он је такође могао постати предмет емпиријског интересовања - интересовања којем су нове, индискретне методе снимања само ишле у прилог. Чини ми се да је откриће свакодневног живота, чију историју овде нећемо наводити, ${ }^{12}$ било у два аспекта од примарног значаја за увођење техника аудиовизуелног снимања као ресурса за интерпретативна социолошка истраживања.

Схваћено у топографском смислу, „откривање свакодневног живота“ у почетку се односи на један (поновни) развој области стварности коју су социолози углавном изгубили из вида у својим теоријским висинама и методолошким дубинама. Дуго је грађење све сложенијих теоријских структура у социологији било готово у потпуности ограничено на преуређивање и проширивање старијих теоријских структура; „емпиријска“ грађа је представљала сметњу. Паралелно са овом аутономизацијом развоја теорије текла је херметизација методолошког дискурса, тонући све дубље у подручје предуслова и једва одржавајући везу са предметом социолошког сазнања. Будући да се увек претпостављало да је ствар на сигурном, оба развоја догађаја довела су до деградације и осиромашења описног знања у друштвеним наукама - чему се у последње време приговарало и у социологији немачког говорног подручја. ${ }^{13}$ Превазилажење овог социолошког губитка стварности је био један од циљева који су били заједнички интеракционистичким и феноменолошким истраживачким приступима који су се појавили 1960-их. Њихов фундаментални аргумент да теоријске конструкције друштвених наука морају остати повезане са искуственим светом њихових актера био је усмерен против анемичног развоја теорије, као и против аутизма методолошког дискурса. Стављајући занемеран свакодневни свет и његову типичну описну својственост у центар социолошке пажње, ови истраживачки приступи утабали

\footnotetext{
${ }^{11}$ Уређено издање транскрипата ових „Никсонових трака“ објављено јеподнасловом Председнички йранскрийй (The Presidential Transcripts) 1974. године и убрзо је постало бестселер.

${ }^{12}$ Види: Bergmann \& Srubar 1985.

${ }^{13}$ Матес на 21. Немачким данима социологије у Бамбергу 1982. године (Matthes 1983: 22). 
су пут истраживачком ресурсу - који као ниједан други одржава друштвени догађај у изворном облику и тако га на потпуно нов начин чини доступним анализи - техникама аудиовизуелне репродукције.

Чак и више него кроз тематску преоријентацију ка свакодневном свету, интеракционистички и феноменолошки истраживачки приступи су се користећи одређени методолошки принцип побринули за то да инструменти за снимање постану незаменљив ресурс за интерпретативна социолошка истраживања. Овај принцип се састоји у томе да се, не као код Диркема (Durkheim 1961: 115 и даље) узимају у обзир социолошке чињенице попут ствари спољашњег света, већ да се објективна датост социолошких чињеница концептуализује као постигнуће које се континуирано догађа у интеракцијама актера, као стварање, као процесно дешавање, као пракса. Једна од централних истраживачких максима етнометодологије, у Гарфинкеловој формулацији (Garfinkel 1967: 33), каже да „сваку карактеристику смисла, чињеничности, објективности, одговорности, заједништва неке активности треба третирати као условно остварење друштвено организованих уобичајених пракси“. И Оверман и сарадници (Oevermann et al. 1979: 423) оправдавају секвенцијално-аналитички приступ објективне херменеутике аргументом „да је репродукција структуре интеракцијских процеса који карактеришу случај и конструишу латентне структуре значења, стални и непрестано оперативан процес“. Идеја о самообнављајућој стварности у процесима и поступцима, која сама по себи није нова у социологији (може се лако пратити још у радовима Зимла, Мида и Шица), постаје значајнији проблем онда када се сагледају последице по емпиријску истраживачку праксу проистекле из те идеје. Ако се више не ради о опипљивим особинама, већ о низовима догађаја који се одигравају, одмах се јавља потешкоћа у томе како се ти процеси, који се увек одвијају у времену, могу евидентирати у њиховој тренутности и догађајности и на тај начин учинити доступним за анализу.

У овом тренутку је занимљиво сагледати како се у Зимловим теоријским разматрањима појављује идеја да новој врсти инструменталног приступа одговара концептуална редефиниција предметног подручја социологије. Користећи аналогију организма и друштва, Зимл у својој Социологији развија аргумент да је друштвена наука до сада била ограничена на „велике органе и системе“ (породичне форме, класне формације, државе, итд.) и неупадљиве, превиђене пролазне облике социјализације: „Изнова и изнова се друштвеност међу људима учвршћује и ослабљује, у вечитом току и пулсирању које спаја појединце, чак и тамо где се не уздиже до стварних организација. Овде је, да тако кажемо, реч о микроскопско-молекуларним процесима у људском материјалу, који су, заправо, стварне активности које повезују или опредмећују макроскопски фиксиране ентитете и системе“ (Simmel 1968: 15). А да би појаснио тежину свог новог начина сагледавања за социологију, Зимл наставља неколико редова касније: „Можда ћемо на основу овог знања постићи за друштвену науку оно што је почетак микроскопије значио за науку о органском животу““ (Simmel 1968: 16).

Зимл је само указао на аналогију проширења потенцијала научног знања кроз технички развој, али је није сматрао реалном могућношћу за социоло- 
гију. Међутим, започео је преформулисањем предмета социологије на такав начин да би технички посредована могућност снимања, чувања и репрезентације друштвеног догађаја који својом реализацијом увек нестаје, преко свог архивског значаја, могла постати примарни емпиријски ресурс интерпретативне методологије истраживања. Јер чим неко замисли вечито флуидне, несталне процесе социјализације као основну тему друштвених наука, за социологију као науку емпиријских процеса поставља се питање како се може доћи до ове пролазне појаве. Директан пут води од идеје друштвене репродукције стварности на делу до техника аудиовизуелног репродуковања друштвених процеса. Супротно Зимловој заводничкој метафори микроскопије, код анализе процеса социјализације кључни проблем, међутим, није њихов ред величине, већ њихова временска структура. У интерпретативној социологији, уређаји за аудиовизуелну репродукцију не функционишу као инструменти за увећање, већ као временске машине. Они омогућавају друштвеном истраживачу да сачува друштвени догађај у свом стварном временском следу и да истовремено манипулише његовом временском структуром на било који, па и на реверзибилан начин.

\section{III}

То што се догађаји поново појављују и нестају заправо је тривијална спознаја - тривијална, јер у свакодневном животу увек рачунамо на пролазност догађаја и увек располажемо социјално институционализованим решењима за овај структурални проблем. Догађај се не раствара у ништа након што се десио, већ постаје - претходно дешавање. Знамо да су догађаји пролазни, али такође знамо да се прошли догађаји могу памтити, именовати, тематизовати и призивати у разговору са другима. Ове технике конзервације су од фундаменталног значаја за коегзистенцију људи; не постоји нама позната етничка група код које они не могу да се нађу. ${ }^{14}$

За разлику од уређаја за аудиовизуелну репродукцију, који омогућавају регистративну конзервацију догађаја, лингвистичка репрезентација догађаја који је прошао увек је реконструкиијска конзервација. Да би се ово поређење диверзификовало, у наставку су описане три карактеристичне структурне разлике.

1. Фиксирање друштвеног догађаја у слици и звуку је процес који не захтева снимање и обраду овог догађаја у значењском контексту и, у принципу, може бити технички аутоматизован. ${ }^{15}$ Насупрот томе, ретроспективна - језичка или нејезичка - репрезентација догађаја увек подразумева тумачење. Накнадне тематизације формирају секундар-

\footnotetext{
14 Упореди: Schotts 1968. Рад о историјској свести неписмених народа.

${ }^{15}$ Потпуно је друго питање да ли истраживачи друштва у свом раду ову аутоматизацију сматрају пожељном. Упоредити забаван спор Маргарет Мид и Грегорија Бејтсона о употреби фотоапарата у њиховој студији о карактеру људи са Балија: Brand, Bateson \& Mead 1976: 39.
} 
ни контекст значења у поређењу са примарним контекстом догађаја који се дешава, у којем се прошлост и њено садашње значење наново стварају интерпретативно, односно реконструишу. ${ }^{16}$ Без таквог интерпретативног својства - под претпоставком одговарајуће меморијске способности/вештине - тематизација прошлог догађаја би била могућа само у облику понављања налик папагају без разумевања истог. Наравно, аудиовизуелни снимак догађаја такође мора да интерпретира гледалац, али овде је пресудно да се интерпретативна трансформација догађаја одвија у једном случају након регистративне конзервације, а у другом током реконструкцијске конзервације.

2. Зарад реконструкције, репрезентације и преношења прошлих догађаја, у свакој језичкој заједници су се развили различити комуникативни облици. То су наративни или - како ми кажемо - реконструкцијски жанрови ${ }^{17}$, које свако ко жели да буде способан да исприча причу, учествује у трачевима или да извештава о нечему, мора да посматра и савлада. Реконструкцијски жанрови чине подскуп комуникативних жанрова, који се генерално могу посматрати као историјско и културолошко специфични, друштвено успостављени модели решења за структурне „комуникативне проблеме“. Комуникативни жанрови обично имају релативно висок ниво институционализације и релативну аутономију у односу на ситуационе и контекстуалне услове. Релативна аутономија реконструкцијских жанрова, као њихова структурна карактеристика, ствара специфични проблем утолико што отвара могућност ,„реконструкције“" независне о стварном претходном догађају, тј. могућност фиктивних прича. Иако је реконструкцијска конзервација друштвених догађаја везана за дате, жанровски специфичне принципе презентације, регистративна конзервација не подлеже ниједној таквој обавезној форми. Аудиовизуелно фиксирање је у основи пасивно; оно само и једино прати догађаје, али не и захтеве за једну успешну причу; за разлику од приповедања приче, оно се не концентрише на „важно“, занемарује „неважно“, већ - у идеалном случају - настоји да континуирано документује друштвену појаву током довољно дугог временског периода. Наравно да би се такав снимак могао - као што би се могао и Лежеов 24-часовни филм - резовима и монтажом накнадно прерадити у реконструкцију са основном наративном структуром. Последица овог процеса приповедања је, међутим, да је прошли друштвени догађај нераскидиво проткан и допуњен накнадним тумачењима других, чак и у раној фази свог очувања.

3. Процес аудиовизуелног фиксирања друштвеног догађаја тече синхроно са његовим трајањем; завршава се чим се радња оконча и/или се

\footnotetext{
${ }^{16}$ Види: Luckmann 1981: 518.

17 Ова - некима можда својевољна - употреба појма „реконструкцијски“ као и концепта „реконструкцијских жанрова“ објашњена је у: Luckmann \& Bergmann 1983.
} 
дође до краја траке за снимање. Чим се догађај заврши, могућност његовог регистративног конзервирања се једном заувек исцрпљује. Верзије снимања које не постоје до тог тренутка нису доступне. Конзервација која је дефинитивно завршена у том смислу није могућа у случају ex post реконструкције. За сваки догађај који се догодио постоји увек више од једне верзије реконструкције; нема реконструкције која се не може проширити или за коју није могућа никаква алтернатива. Како се ова бесконачност могућности реконструкције не доживљава као ноторна, нерешива дилема у свакодневној пракси резултат је чињенице да се свака реконструкција одвија у комуникативном контексту чак и ако је само замишљена - што је сазнање које драстично ограничава бесконачно велики број могућих верзија реконструкције. Реконструише се увек само за одређене примаоце, имајући у виду одређени циљ, под одређеним - нпр. временским - ситуационим условима, итд. Другим речима: свака реконструкција је прилагођена одговарајућем контексту релевантности и неизбежно поприма ову контекстуалну оријентацију. То, међутим, значи да је свака реконструктивна конзервација једног друштвеног догађаја увек контекстуализована утолико што је неизбежно прожета околностима њене производње.

Упоређивање регистративне и реконструкцијске конзервације није се развило само по себи. Приписује му се специфичан значај аргумента који постаје евидентан чим се повеже са тезом да емпиријски подаци обрађени у конвенционалним социолошким истраживањима имају све карактеристике реконструкцијске конзервације. Дакле, моје тврдње су: 1. да су сами подаци (а не само њихова каснија обрада) резултат секундарних процеса формирања значења који су се неизбежно надградили на примарни контекст значења, ако нису избрисани; 2. да се у тим подацима социјални оригинал - делом врло згуснут - трансформисао у форму реконструкцијских жанрова и 3. да су ти подаци у свим својим описним компонентама обликовани кроз специфични контекст и зависни од њиховог стварања и употребе. Основни мотив за окретање социолога интерпретативне социологије ка техникама регистративне конзервације лежи у томе што подаци конвенционалних социолошких истраживања, због ових процеса трансформације који су за њих конститутивни - а и сами углавном неистражени - пропуштају да локализују или чак и анализирају социолошки догађај у његовом реалном току и значењској структури. „Подаци“ клизе као филмска трака преко онога што они тврде да представљају; резултат је врло мутна слика на којој више не могу да се разликују контуре објекта и ефекат филтера. Узимајући у обзир најчешћу врсту података по којима се традиционална друштвена истраживања управљају, ова критика се може конкретизовати на следећи начин:

- Велики део емпиријских друштвених истраживања и даље ради са већ постојећим реконструкцијским описима, јер су доступни у облику званичних података и података произведених у процесу. Диркемово истраживање само- 
убиства је парадигматични случај за ово, који су критички испитале бројне студије из перспективе интерпретативног истраживања (нпр. Douglas 1967; Atkinson 1979). Оно што је заједничко овим студијама је да статистику самоубистава сматрају нумерички сажетим и високо трансформисаним резултатом друштвеног процеса тумачења и категоризације у коме су одговорни званичници и медицински представници реконструисали вероватне самоубилачке историје мртвих људских тела. Овај процес реконструкције прећутно се претпоставља у самим статистикама, али је истовремено из њих у потпуности уклоњен; самоубиство се појављује као пука друштвена чињеница. Међутим, с обзиром да се у овом процесу социолошке реконструкције и интерпретације одлучује шта се касније појављује у статистици и обрађује као datum, социологија не би требало непромишљено да игнорише овај процес, већ би морала да попут Сакса (Sacks 1963: 8) који у свом раном програмском есеју, такође изричито захтева да то буде њихова истинска тема: „Истраживање се мора започети о томе како се дошло до одлуке да је почињено самоубиство и о томе како предмет мора бити замишљен да би се о њему говорило као о 'извршењу самоубиства', ово су прелиминарни проблеми за социологију. Пошто смо (про)извели процедуралне описе изградње класификације самоубистава, може се испоставити да управо категорија и методологија њене примене представљају занимљиве социолошке проблеме“. У неколико етнометодолошких радова (укључујући Garfinkel 1967: 11-18; Sacks 1972; Smith 1983) касније почиње да се спроводи овај истраживачки програм. На исти начин као и статистика самоубистава, статистике о криминалу, болести, несрећама и друге друштвене статистике такође су подложне етнометодолошкој критици, која генерално тврди да форма конзервирања ових типова података без оклевања користи основне друштвене процесе реконструкције и трансформације тако што их и уклања без трага.

- Где год се социолошка истраживања не могу ослонити на постојеће нумеричко-статистичке описе друштвеног света као податке, она их стварају за себе - углавном користећи свакодневна схватања неког проблема. Заправо, нема потребе за било каквим даљим доказивањем да интервју, као инструмент прикупљања података, друштвене чињенице може само да реконструише. Оно што интервју пружа у погледу података су типичне изјаве о друштвеним процесима и чињеницама. Ове изјаве уграђене су у засебан, рефлексиван интерпретативни контекст - одређен друштвеним догађајима о којима се расправља - који, у зависности од степена отворености и стандардизације интервјуа, у мањој или већој мери одређује испитаник (или вероватније истраживач), а његова комуникацијска структура је мање или више експлицитно наративна. За интерпретативне приступе, који се - попут анализе конверзације и објективне херменеутике - у потпуности фокусирају на анализу процеса социјалне интеракције и њихове (примарне) значењске структуре, интервју је стога испитивачки инструмент, који пружа реконструкционо реформулисане податке и стога податке који се могу анализирати само у врло ограниченом обиму. Оверман о овом приступу даје драстичну констатацију (Oevermann 1983: 286): „У поређењу са прикупљањем и анализом природних протокола друштвених 
процеса, метод интервјуисања, бар у свом стандардизованом облику, није најбољи, већ погрешан пут емпиријског друштвеног истраживања.“ (Ако се у овом тренутку сетимо концепције наративног интервјуа, постају очигледне значајне разлике између различитих приступа интерпретативног истраживања. О овоме више ускоро.)

- Коначно, емпиријски истраживач социологије бави се трећом врстом података када примењује метод посматрања са учествовањем. Овде нису саговорници ти који дају изјаве о друштвеним питањима када су питани, овде је он [емпиријски истраживач] тај који језички формулише перципиране друштвене процесе и чува их у виду теренских бележака, протокола посматрања и разговора. За разлику од интервјуа, овај метод пружа друштвеном истраживачу могућност да друштвени догађај прати у његовом стварном току, а није реткост у његовим посматрачким записницима наћи и прецизне описе и дословне транскрипте процеса интеракције. Овај регистративни облик бележења се, наравно, брзо исцрпљује: имамо само врло ограничену способност памћења и репродукције аморфне масе догађаја који се тренутно дешавају. Стога посматрач који учествује нема другог избора него да забележи друштвене догађаје којима је присуствовао, углавном у типизирајућој, резимирајућој, реконструкцијској форми.

Треба се помирити са чињеницом да подаци којима оперише једно конвенционално друштвено истраживање, уз врло мало изузетака, чувају друштвене чињенице које се приказују у њиховој реконструисаној форми. Другим речима, подаци су крајњи резултат трансформативног процеса, чији механизми деловања још увек у великој мери нису истражени, помоћу којих се смислено структурисани, организовани друштвени догађај in situ замењује типизиpajућом, наративном, у основи интерпретативном представом ex post. Овде је пресудно да је интерпретативно-реконструкцијска трансформација догађаја већ ушла у саме податке и да истраживач нема никакве шансе да преокрене овај процес: догађај сам по себи је нестао, једино је остао доступан податак његове реконструкције.

У студијама књижевности било би потпуно незамисливо да сажеци, интерпретације и мишљења о књижевним делима која су накнадно настала постану главни предмет истраживања уместо самих књижевних дела. До сада је социологија подразумевала да њени подаци имају постериори-реконструктивни карактер. Претпостављам да ова чињеница није постала проблем за социологију јер перспектива ових социолошких података тачно одговара перспективи из које се односимо према друштвеним процесима у свакодневници. Изненађујуће је да се потврда ове претпоставке налази тамо где би се очекивала алтернатива типу реконструкцијских података - у употреби техника аудиовизуелног снимања у интерпретативним социолошким истраживањима.

Технички уређаји за репродукцију толико су фасцинантни за друштвена истраживања јер први пут омогућавају корисницима да друштвени догађај региструју у њиховом реалном, уочљивом току, уместо да га накнадно - уз одговарајуће трансформације - реконструишу. „Подаци“ који су настали на овај 
начин више не одговарају реконструкцијском начину конзервације друштвених процеса, који је толико познат професионалним социолозима као и социолозима лаицима. ${ }^{18}$ Ово ставља кориснике нових техника фиксирања пред нови методолошки проблем: будући да су сви уобичајени методолошки поступци развијени према и за податке реконструкцијског типа, сада се морају изнаћи методе за руковање регистративно снимљеним подацима. Значајно је да се решење овог проблема често састоји управо у стављању нових техничких уређаја за репродукцију у службу познате, реконструкцијске конзервационе праксе. Два примера који следе говоре о томе.

Веома популаран интерпретативни метод прикупљања података данас је отворен, конкретан и наративан - то је интервју, за који је један од основних предуслова да се разговор са испитаником снима. Оно што се бележи су између осталог реконструкције биографија, процеси политичког одлучивања, дакле интерпретације протеклих друштвених догађаја који су прибављени у секундарном контексту интервјуа. Када би се социолошки интерес првенствено усмерио на реконструкцију и обрасце интерпретације испитаника и на истински контекст комуникације у интервјуу, тада би снимци заправо чинили нереконструктивну базу података. Међутим, с обзиром да се евалуација наративног интервјуа обично фокусира на то да ухвати променљиве реконструкцијске интерпретације кроз стварне животне процесе испитаника ${ }^{19}$, квалитет снимања података у потпуности је подређен квалитету реконструкције. На реконструктивни облик социолошких података који је толико познат свакодневном разумевању и традиционалним социолошким истраживањима скоро да уопште не утиче увођење техничких уређаја за репродукцију у случају наративних интервјуа. И желео бих да истакнем да произвољност овог поступка - посебно код студената - не дугује само чињеници да је у њиховом случају привлачност квалитативних метода истраживања комбинована са умирујућим гледиштем да не треба одбацити реконструкцију свакодневне перспективе друштвених догађаја.

Још један пример очигледно дубоко укорењене, тврдоглаве тежње да се само реконструкцијски конзервати друштвених догађаја сматрају и третирају као социолошки релевантни подаци може се наћи у образовној пракси анализе конверзација. Врло често се понавља да већина студената има велике потешкоће у прихватању снимка и транскрипта природног разговора као предмета проучавања који је сам по себи доступан за анализу. Редовно се након завршетка дела транскрипције прво припреми нека врста парафразираног препричавања забележеног догађаја, а затим, уместо транскрибованог снимка, парафразирано препричавање постане предмет даљег аналитичког разматрања. Природност којом студенти прелазе на овај међукорак чини ми се у потпуности симптоматичном - симптоматичном за стидљивост и неспособност традиционалних

\footnotetext{
${ }^{18}$ Израз „професионални социолози као и социолози лаици“ се редовно јавља у Гарфинкеловим радовима; нажалост, често је погрешно схваћен као полемички покушај да изједначе разлике између социолога и не-социолога (Garfinkel 1967).

19 Тако одлучно тврди Шице (Schütze 1983: 284).
} 
социолошких истраживања да емпиријски објекат учине објектом анализе, пре него што његову регистративну конзервацију трансформишу у познати облик реконструкцијске конзервације, пре него што Лежеов филм буде монтиран у наративни облик. Иза ове методолошке стидљивости не стоји ништа друго него неартикулисани отпор да се одустане од познатог свакодневног практиковања реконструкцијског својства и конзервације друштвених процеса, а прихвати конститутивно-аналитичка (konstitutionsanalytischen) перспектива која приступа репродукцији друштвене стварности кроз делање.

\section{IV}

Испоставило се да увођење уређаја за аудиовизуелну репродукцију у интерпретативна социолошка истраживања карактеришу два супротна, наизглед парадоксална момента. С једне стране, употреба ових техника снимања манифестује се као окретање ка свакодневном животу утолико што банални, природни процеси интеракције који се у социјалним истраживањима обично занемарују постају примарни предмет истраживања. С друге стране, употреба ових техника репродукције такође изазива удаљавање од свакодневног живота, јер њихов начин чувања отвара перспективу анализе која је супротна трансформишућој пракси реконструкције актера свакодневног живота. Да бисмо могли да пружимо информације о резултату до којег ова два супротстављена момента кретања воде, прво је потребно позабавити се пажљивије питањем како се у интерпретативној истраживачкој пракси поступа са техничким уређајима за репродукцију, када нису у служби познате конзерваторске праксе.

У последњих неколико година посебно су се обликовала два приступа интерпретативног истраживања која су у својим анализама у великој мери ограничена на снимања и транскрипције процеса природне интеракције - етнометодолошка анализа конверзације и објективна херменеутика. У ретким покушајима да се уведе ред у разноликост интерпретативних метода, стилова рада и истраживачких група, оба смера су окарактерисана као противречна. ${ }^{20}$ Заговорници ова два истраживачка приступа до сада нису примећивали једни друге - отуда вероватно и прејаке тврдње о њиховој оригиналности.

Овде сматрам да, упркос свим израженим разликама, оба приступа имају низ изненађујућих и занимљивих заједничких ствари. То почиње чињеницом да су у оба случаја дотични методолошки принципи, какви се данас користе у делимично канонизованом облику, резултат дуготрајног и мукотрпног процеca, током којег тек с интерпретативним радом на снимцима разговора и транскриптима долазе до изражаја одређени методолошки облици руковања таквим материјалима и успостављају се као традиција. У оба случаја једна од главних потешкоћа била је ослобађање од традиционалне - сада бих рекао: реконструкцијске - методе и свести о подацима друштвених наука и проналажење начина

\footnotetext{
${ }^{20}$ О томе код: Soeffner 1982: 23.
} 
и средстава да нови квалитет регистративних форми конзервације дође до изражаја. Ова заједничка развојна историја је значајна јер даје основ за претпоставку да су методолошке паралеле можда посредоване сличним инструментализованим приступом друштвеној стварности.

Методолошке подударности између анализе конверзације и објективне херменеутике не могу да буду овде детаљно представљене, нити да се о њима расправља. Стога ћу споменути само неколико, а затим ћу се пажљиво бавити двема од ових сличности, које су од посебног значаја за моју наредну аргументацију. $^{21}$

- Оба истраживачка приступа претпостављају да су забележени и транскрибовани догађаји сами по себи структурирани на смислен начин и да је суштински циљ анализе утврђивање ове смислене структуре и структурисања уграђених у делање.

- Свако могуће знање о контексту сцене/поставке интеракције које може бити доступно истраживачу се иницијално крије у анализи.

- Анализа конверзације и објективна херменеутика не покушавају да закључују о смислу исказа кроз претпоставке и закључке о намерама или вредносним оријентацијама (ис)казивача или кроз специфично разумевање реципијента.

- Оба приступа подлежу „правилу штедљивости“ утолико што приликом тумачења транскрипта претпостављају што је дуже могуће да су исказ и мотивација актера за исказ у распону нормалног.

Ова (проширива) листа сличности би, наравно, требало још једном да нагласи, а не да прикрије чињеницу, да питања која се анализом конверзације или објективном херменеутиком постављају пред текст транскрипције указују на врло различите правце. Место где се преко својих сличности путеви анализе конверзације и објективне херменеутике разилазе, може се барем наговестити ако се пажљивије погледају два основна методолошка принципа која су од централне важности за ова два приступа.

Оба приступа одликује - у поређењу са свим осталим квалитативним, као и квантитативним правцима - да се њихов поступак у основи води премисом о поретку, која каже да се ниједан елемент текста који се појављује у транскрипту интеракције не сматра случајношћу, већ увек делом репродуковане уређености радње актера. Харви Сакс је већ формулисао ову методолошку претпоставку о уређености у својим ранијим Предавањима (Lectures) $)^{22^{*}}$ из 1966. године, и скицирао следећу слику ради објашњења: „друштво“ се у већини социолошких теорија појављује као нека врста машине са низом рупа; спреда ова машина избацује ,занимљиве“, „добре“ проблеме, позади само смеће. Фокус социолога је обично у потпуности усмерен на велике, важне проблеме, а остало се сма-

${ }^{21}$ Засновано је на поређењу, с једне стране: Oeverman et al. 1979, и с друге стране: Garfinkel 1967; Sacks et al. 1974; Bergmann 1981; Levinson 1983.

${ }^{22^{*}}$ Harvey Sacks - Lectures on Conversation, Volume 1. Доступно за преузимање преко интернет адресе: https://onlinelibrary.wiley.com/doi/book/10.1002/9781444328301 (йpuм. ped.). 
тра несређеном случајношћу и стога нечим невредним истраживања. Насупрот томе, Сакс сада поставља као методолошки постулат да се не одлучује унапред који су друштвени феномени погодни као социолошки објекти истраживања, већ: „се може, алтернативно, претпоставити да постоји ред у свим тачкама““.23 Овим постулатом „ред у свим тачкама“ (“order at all points”) - социолози су ослобођени обавезног образовања о „великим“ темама, али су истовремено подвргнути и строгом захтеву да у својим истраживањима докажу уређеност друштвене појаве, а самим тим и могућност њене социолошке анализе.

Еквивалент конверзацијско-аналитичкој премиси „ред у свим тачкама“ може се наћи у објективној херменеутици у методолошком принципу: „како би објаснили мотивацију за сваки елемент текста садржан у протоколу, никада не посматрати елементе текста као производ случаја. Управо се мотивација за наизглед безначајни елемент текста често покаже као полазна основа за каснију централну линију тумачења. Ако се неко упусти у објективно херменеутичку интерпретацију текста, онда мора одабрани одломак текста интерпретирати у његовој целости“ (Oevermann et al. 1979: 394).

У основи, методолошка премиса о поретку је логична импликација одлуке да се регистративна конзервација друштвеног догађаја учини примарним истраживачким материјалом. Зато што би свако прелиминарно аналитичко прописивање „безначајних“ елемената мрежом секундарних интерпретација неконтролисано покрило фиксиране, саме по себи смислено структуриране догађаје и на тај начин прикрило тачно оно што регистративни облик конзервације обећава да разоткрије. Настојећи да се друштвени догађаји сачувају у својој догађајности, анализа конверзације и објективна херменеутика поставили су себи правило да се са снимака интеракцијских процеса током процеса транскрипције не брише ништа што на први поглед може изгледати ирелевантно или нетачно. Дакле, у транскриптима се бележе сви лапсуси, понављања, паузе итд. и користе се за бележење специфичности артикулације, преклапања исказа, усмеравање погледа; између осталог, у анализи конверзације развијен је врло диференциран систем симбола транскрипције. ${ }^{24}$

Претпоставка о уређености није евидентна само при креирању и тачности транскрипата, она се такође манифестује у типу објекта на које је - на основу снимака и транскрипата - усмерена аналитичка односно интерпретацијска пажња. Било да се ради о ситуационим варијацијама у чину поздрављања, самокорекцијама говорника, кашљу, исказима прекривеном смехом или нечем сличним, увек је методолошка премиса о поретку била та која је ове минималне објекте учинила вредним тематизације.

У овом тренутку може се разјаснити фундаментална разлика између анализе разговора и објективне херменеутике. Обе се баве истим наизглед марги-

\footnotetext{
${ }^{23}$ Методолошке примедбе Сакса, које се на разним местима налазе у његовим Предаватима сабрао је, уредио и одштампао као предговор Џеферсон (Jefferson 1981: 1-8).

24 Упореди компилацију транскриптивних симбола коришћених у анализи конверзације датих у додатку: Sacks et al. 1974: 731-734.
} 
налним и неважним феноменима интеракције, али се разликују по контекстима у којима интерпретативно локализују ове феномене. За објективну херменеутику, специфична структура случаја - која се треба утврдити - формира контекст уређења у којем се појединачни елемент текста може описати као мотивисан, тј. производ који није случајан. На пример, мајчин „кашаљ“ који се појављује у транскрипту породичног разговора тумачи се у објективном херменеутичком тумачењу као израз конфликта који карактерише структуру случаја у целини: „Кашаљ објављује слаб соматски протест против згушњавања простора интеракције, која се до сада мењала: а) васпитни рационализам и у овом ограниченом, образовном смислу: отвореност и б) сакривање себе - форсирање компромиса. (...) Несвесни конфликт (...) је представљен тако што сопствено 'ја' жели да говори о себи, а да истовремено жели (...) да се сакрије. Оба треба да се десе у буквално једном даху. Кашаљ указује на ову секвенцијално згуснуту ситуацију“ (Allert 1984: 72).

Насупрот томе, за анализу разговора, организациони принципи интеракције, које треба утврдити независно од случаја, чине контекст уређења у којем појединачни догађај може да се одреди као методолошки произведен објекат који на тај начин губи свој карактер случајности. Тако се у радовима анализе разговора показује да је „смејање“ систематски произведена, друштвено организована активност која захтева висок ниво координације учесника у интеракцији и која се методолошки појављује на одређеним местима - дакле не само након шале, већ такође нпр. тамо где се двосмисленим формулацијама, суптилним опсценостима или деликатним темама тежи постизању међусобно потврђене интимности друштвеног односа учесника: „смех у потрази за интимношћу“ (Jefferson et al. n. d.).

Још један основни методолошки принцип, који је од фундаменталне важности у анализи конверзације, као и у објективној херменеутици, јесте да се обе у свом методолошком приступу воде принциипом анализе секвенци. Овај принцип иницијално не изражава ништа друго осим преноса премисе о поретку у временску структуру интерактивног процеса, тј. интерпретатор методолошки претпоставља да редослед појединачних исказа учесника у интеракцији чини сопствени поредак. Ни овај принцип не изненађује, јер га треба схватити као директну последицу основне идеје интерпретативних приступа о стварности која се репродукује кроз друштвена делања. Овај појам проналази свој значајан израз у специфичном ограничењу интерпретације којем су подложне анализа разговора као и објективна херменеутика. Обе себи забрањују да кроз опције коју им омогућује снимање и транскрипт користе информације о каснијем интеракцијском процесу за интерпретацију претходног исказа. Колико се два приступа слажу по овом питању, може се јасно видети из чињенице да су оба приступа, независно један од другог и у готово идентичним формулацијама, била у основи критична према добро познатој студији терапијског дискурса Лабова и Фансхела (Labov \& Fanshel 1977), јер су у њој за интерпретацију исказа без оклевања коришћене информације које се појављују тек касније у тексту (уп. Oevermann et al. 1979: 425 и Levinson 1983: 352). 
Анализа секвенце је методизација идеје друштвеног поретка који се репродукује у интеракцији. Оно што је њој од суштинске важности је обавеза интерпретатора да увек буде на истом нивоу као и стварна интеракција, а то значи да се одрекне - тако заводљивог - положаја свезнајућег социолошког демијурга. Управо снимци и транскрипти омогућавају кориснику да се по сопственој вољи креће напред-назад у времену. Међутим, секвенцијално-аналитички поступак користи ове временски манипулативне могућности само на врло дисциплинован начин, јер настоји да утврди стварну процесуалност друштвеног поретка који су успоставили учесници у интеракцији и, због тога, мора да одржи нетакнутим временски ток процеса интеракције.

У погледу концепта секвенцијалности, сада се може уочити већ поменута разлика између анализе конверзације и објективне херменеутике. У анализи конверзације, „секвенцијалност“ означава ланац узастопних исказа и активности, независно од конкретне ситуације. Ова концепција се заснива на запажању да два хронолошки узастопна исказа за учеснике у интеракцији нису само у серијској вези, већ и у условном контексту. Искази се повезују у секвенце тако што иницијативни исказ генерише више или мање снажна нормативна очекивања у погледу одговарајућег накнадног исказа који ће прималац одабрати. Захваљујући свом антиципативно-нормативном квалитету, принцип секвенцијалности такође може служити учесницима у интеракцији као основни ресурс за интерпретацију. Јер секвенцијални оквир очекивања, који генерише неки исказ, ствара непрекидно ажурирани, локални контекст интеракције у који је уграђен одговарајући следећи исказ и уз помоћ којег се може одредити његово значење и карактер радње. Секвенцијално увезивање исказа је стога незаменљив принцип за оне који ступају у интеракцију како би постигли интерсубјективно разумевање и одржали га под надзором. Будући да анализа конверзације тематизује секвенцијалност у овом смислу као универзални организациони принцип разумевања, она мора усмерити своје напоре да из појединачних и ситуационо утврђених карактеристика текста интеракције аналитички издвоји секвенцијални редослед који није специфичан за случај. Бројне конверзационо-аналитичке студије о структурним карактеристикама појединачних форми интеракцијских секвенци (поздрав-отпоздрав, питањеодговор, итд.), о формалним механизмима секвенцирања и о техникама моделирања секвенци, свака на свој начин, покушавају да створе програм независан од контекста - али ипак осетљив на контекст - односно, да успоставе одређење секвенцијалне организације друштвене интеракције. ${ }^{25}$

За разлику од његове методолошке важности у анализи конверзације,

\footnotetext{
25 Ово двоструко одређивање зависности од контекста и осетљивости на контекст, који је кључан за разумевање приступа истраживања анализе конверзације је уведено код Сакса и сарадника: „Мора постојати неки формални апарат који је сам по себи без контекста, на такав начин да у локалним случајевима свог деловања може бити осетљив и показати своју осетљивост на различите параметре друштвене стварности у локалном контексту. Од неких аспеката организације конверзације мора се очекивати да имају овај статус без контекста, који је осетљив на контекст“ (Sacks et al. 1974: 699).
} 
принцип анализе секвенци у објективној херменеутици користи се за одређивање специфичне структуре случаја. Ова концепција се заснива на претпоставци да се индивидуализовани систем интеракције континуирано репродукује, и да се његова појединачна структура случаја може реконструисати само пратећи селективност типичну за случај која се јавља током интеракције. У секвенцијално-аналитичкој интерпретацији објективне херменеутике се као први корак уз помоћ конкретног исказа објашњавају опције отворене за систем интеракције, а тек након тога се посматра - увек уз коришћење транскрипта коју од ових опција систем интеракције бира у даљем току. Репродуктивна селективност случаја - тј. његова индивидуална структура - појављује се секвенцијално, а пратећи овај стварни процес селективности, анализа секвенце има за циљ откривање индивидуалне структуре случаја. Док анализа конверзације у свом аналитичком поступку секвенце покушава да утврди неслужбене, „анонимне“ принципе организације интерактивне секвенце, у поступку анализе секвенци код објективне херменеутике ради се управо о идентификацији „индивидуалне“ селективности система интеракције која је специфична за случај.

Анализа разговора и објективна херменеутика овде су разматране упоредо с обзиром на неке од њихових основних методолошких принципа, јер су то једина два интерпретативна приступа која своју истраживачку праксу заснивају на примени техничких медија за репродукцију, а да се ови регистративни процеси не користе само као помоћ у реконструкцији података. Оба приступа су развила своје методологије независно један од другог у раду са овом новом врстом података. Чињеница да се слажу у многим методолошким тачкама упркос описаној континуираној разлици у њиховим циљевима сазнања може се разумети само из паралелности њихових напора да методолошки оправдају специфичност снимања овог типа података.

Горе је аргументовано да, иако технички уређаји за репродукцију у фокус стављају банални свакодневни живот, они парадоксално отварају перспективу анализе својим начином регистративне конзервације, који је у супротности са праксом реконструкцијске конзервације познате из свакодневног живота. Сада се на основу два представљена методолошка принципа може прецизније објаснити у чему се састоји ова супротстављеност. С једне стране, анализа конверзације и објективна херменеутика суочени су са изазовом да пронађу контекст за сваки текстуални елемент транскрипта, у складу са претпоставком о уређењу, у којем се он може сматрати мотивисаним или методолошки произведеним, барем као неслучајан. Будући да у овој перспективи сваки елемент изговора постаје смислен и доступан за анализу, долази до експоненцијалног повећања материјала који се испитује, што мора изгледати чудно и апсурдно за перспективу реконструкције. Суштинска структурна карактеристика реконструкцијске конзервације је њена економичност, тј. њена способност и њена потреба да брзо синтетише сликовити, типичан опис безбројних детаља тренутног догађаја. С друге стране, секвенцијално-аналитички поступак анализе конверзације и објективне херменеутике подривају перспективу реконструкцијске конзерваторске праксе. Основни принцип анализе секвенци је истовре- 
мено праћење регистрованих друштвених догађаја у њиховом континуитету и сукцесивности и издвајање генеративних принципа односно селективности појединачних случајева у току кретања, које ови догађаји производе у својој уређености и индивидуалности. Међутим, ако догађај није доступан у свом настајућем квалитету догађајности, постоји само могућност реконструкције његовог својства, што увек подразумева ,-графију“, а самим тим поставља идеализујућу „логику представљања“, подложну захтевима доследности, изнад „логике извршења““ оригиналног догађаја. ${ }^{26}$ Да поменемо једну заборављену - и озлоглашену - разлику: технике репродукције омогућавају анализи конверзације и објективној херменеутици да преиспитују „логику на делу“ (“logic in use") друштвеног догађаја на нови начин, уместо да се као раније препуштају заводљивим и умирујућим извесностима својственим ,логици реконструкције“ ретроспективних представа. ${ }^{27}$

\section{V}

Регистративно фиксирање пролазних процеса интеракције у којима се „остварује“ друштвена стварност води, ако се одмах не врати у службу реконструкцијске конзерваторске праксе, до нових методолошких принципа, о чијим се импликацијама до сада мало размишљало. На основу претходно размотрених методолошких сличности између анализе конверзације и објективне херменеутике, желим да закључим своја разматрања развијањем епистемолошке проблематике, која ми се чини од општег значаја за интерпретативну социологију која снимке третира као примарне податке.

Ако се приликом интерпретације забележене и транскрибоване интеракције прате методолошки постулати анализе секвенце и премиса о поретку, пре или касније наилази се на потешкоћу која је упорно избегавана у претходним расправама. Та потешкоћа се састоји у чињеници да се помоћу ових методолошких постулата интерпретатор може ухватити у вртлог детаља који га вуче у све ужи левак унутрашњег хоризонта значења исказа. Захтев да се у свом раду руководи максимом „поредак у свим тачкама““ или да изричито објасни линију мотивације за „сваки елемент текста“ тумачу отвара поглед на детаље забележених догађаја без успостављања доње границе детаљисања. У принципу, сецирање може поново започети на свакој „тачки“, на сваком елементу текста, како би се покренуло тражење претходно скривеног поретка или линије мотивације на још финијем нивоу детаљисања који је претходно прескочен у интерпретацији. На први поглед чини се да је принцип анализе секвенце супротан овој тенденцији ка атомизацији, јер се не ради о синхроном аспекту мотивације појединих елемената, већ о дијахроном аспекту временског стварања реда при-

\footnotetext{
${ }^{26}$ Упореди Прилоге и диксусије о овом понашању значења догађаја in eventu и наративних исказа post eventum y: Koseleck \& Stempel 1973.
}

${ }^{27}$ Види: Kaplan 1964: 8. 
ликом одвијања друштвеног догађаја. Али анализа временског поретка једног друштвеног догађаја може на исти начин упасти у вртлог детаљисања, јер се скраћује временски оквир унутар којег се следи „локална производња“ (Гарфинкел), односно селективност социолошког објекта за одређени случај, све се више приближава тачки у времену.

Динамика детаљисања која се развија у научној интерпретацији фиксиранијих процеса социјалне интеракције можда неће постојати код појединачног друштвеног истраживача током његовог рада; међутим, ако се следи историја интерпретативних истраживачких приступа, њен ефекат је неумитан. Проблеми својствени овој динамици детаљисања можда се могу импресивније илустровати помоћу методолошке паралеле. Георг Зимл (Simmel 1957) се у свом есеју о „Проблему историјског времена“ бавио неким епистемолошким потешкоћама са којима се суочава свака историографија. Полазна тачка његове главне тезе је супротстављање „догађаја“ и „историје“: иако се стварни, проживљени „догађаји“ одликују континуитетом и постојаношћу, „историја“ ове догађаје неизбежно дели на дисконтинуиране делимичне слике, које се увек окупљају око централног концепта. Изузетно је то што историјски садржаји, чим се подведу под такав појам и важе за одређену целину (нпр. „Битка код Зорндорфа“), имају облик доживљене стварности - постојаност и континуитет - наиме „кроз лебдеће априорно знање о томе, такорећи повлачењем идеалне линије“. Међутим, ако се постави питање о деловима и стварном току догађаја сажетим у такву концептуалну целину, континуитет овог догађаја почиње да нестаје: „Али у мери у којој вежбамо све више специјализовану, све прецизније видећу функцију знања о свакој таквој целини, она се распада на пуке дисконтинуитете, од којих је сваки у почетку замишљен као континуирано трајање, све док прогресивна спознаја не изврши исто цепање и самим тим исту девитализацију“ (Simmel 1957: 55). Што се даље наставља са упражњавањем овог процеса фрагментације, односно што се прецизније желе да утврде ствари „онаквима какве су заиста биле“, то се пре пређе праг уситњавања, испод којег поједини атоми догађаја имају „премало смисла сами по себи“ (Зимл), и више се не могу сместити у целокупни ток: „Чини се да постоји општи принцип да се фрагментација појава на елементе, чију суму треба поново схватити, на одређеном нивоу фрагментације поништава индивидуалност саме појаве“" (Simmel 1957: 56). Зимл стога види историјску спознају коју карактерише дубока антонимија: ако се прошли догађај схвати кроз велике обједињујуће концепте, онда његов идеални континуитет заиста репродукује форму догађаја, али његов стварни ток остаје неприступачан у појединачним елементима; с друге стране, ако се догађаји, онакви какви су заиста били, прате на реалан начин - све до „трзања мишића сваког војника“ - континуитет стварних догађаја изостаје.

Чини ми се да су Зимлова разматрања директно релевантна за методолошку проблематику интерпретативне социологије чији се примарни подаци састоје од техничког фиксирања процеса социјалне интеракције. Аудиовизуелни снимци региструју друштвени догађај „онако како се заиста догодио“ на нивоу детаља који је недостижан за модус реконструкцијске конзервације. Ову 
тезу, која до сада није остављала сумњу, сада треба диференцирати у једној суштинској тачки према Зимловим епистемолошким примедбама. Јер шта овде значи „стварно“? „Реалност“ друштвеног догађаја укључује управо оно што његово методолошко фиксирање чини неопходним за социолошку анализу његову несталност. Али управо својим фиксирањем, друштвени догађај губи своју несталност. Сходно томе, аудиовизуелни снимак друштвеног догађаја ни у ком случају није чисто дескриптивни приказ као што се у почетку можда чинило јер је њему, у временски манипулативној структури, у основи својствен конструктивни елемент. Једноставно разматрање може јасно објаснити овај конструктивни карактер аудиовизуелних снимака: ако друштвени истраживач неки видео снимак догађаја гледа у „реалном времену“, односно у сукцесивности и „стварној“ брзини одигравања процеса, онда је то зато што види догађај као непокретну слику, смењивање појединачних слика, успорено, убрзано или по другом редоследу - што је у принципу творевина коју стварају истраживач и његова опрема.

Чињеница да техничко фиксирање процеса социјалне интеракције такође садржи конструктивни елемент, наравно, не поништава претходно направљену разлику између регистративног и реконструкцијског модуса конзервације. Оба се баве различитим принципима градње, што значи да се смер, дужина и ток пута, који се у оба случаја налазе између друштвеног догађаја и социолошког податка, значајно разликују. Међутим, критика формулисана у вези са реконструкцијском конзерваторском праксом конвенционалних друштвених истраживања - да се посвећује премало пажње трансформативном квалитету својих података, мора се утолико пре применити на регистративну конзерваторску праксу интерпретативне социологије. Аудиовизуелни снимци друштвених догађаја за сваког гледаоца поседују заводљиви реализам; али ако се анализом занемари чињеница да је реч о конструисаном реализму, измишљеној аутентичности, постоји опасност да се оно што је фиксирано, без обзира на временску реорганизацију, појави као чиста слика стварности и тако развије неограничену динамику детаља. Анализа конверзације и објективна херменеутика још увек нису систематски обрадиле овај методолошки проблем, али су га сигурно поштовале у својој истраживачкој пракси. О томе сведочи не само претходно поменуто ограничење у интерпретацији, коме се оба приступа подвргавају у поступку анализе секвенци, већ и напори да смање потенцијал детаљисања уређаја за репродукцију ограничавајући их на „интерсубјективно објашњиве детаље““(,intersubjectively accountable details“; Lynch et al. 1983: 06) или на текстуалне елементе специфичне за структуру случаја (Оверман) како би могли да се контролишу.

У овом тренутку интерпретативни социолози могу учити од природних наука, којима није стран увид да технички посредовани прикази стварности увек садрже конструктивни елемент. Развој физике елементарних честица и њена континуирана потрага за последњим градивним блоковима физичког универзума, који постају све мањи и мањи и трају краће и краће, овде су поучни. Чини се да је једна од главних потешкоћа овог истраживања то што ове 
субатомске честице више немају својства ситних ствари, њихова унутрашња структура може се описати само као производ интеракција: „Оно што се чини потребним је темељито преуређење речника природних наука како би се предметни језик честица заменио језиком интеракције атомских догађаја. (...) Јер централни концепт микрофизике је интеракција, или боље, да би се избегла интеракција између ствари, једноставно акција“ (Kisiel 1964: 60, 63). Са овим сазнањем, међутим, визуелни модели и аналогије који су вековима доминирали размишљањем у физици постају неупотребљиви, јер преносе превише статично и опипљиво схватање стварности, а на њиховом месту појављују се аудитивни модели који су динамичнији и увек подразумевају временску структуру.

Чини ми се да је аналогна замена метафора знања потпуно прикладна за интерпретативну социологију. У методолошкој расправи о интерпретативним истраживачким програмима, визуелни модели доминирају у потпуности - ово почиње Зимловом аналогијом микроскопа, а протеже се до недавне Кнор-Цетинине карактеризације етнометодологије као „методолошког микроскопизма“ (Knorr-Cetina 1983: 137). Али управо та визуелна метафора знања подстиче наивни емпиризам при анализирању аудиовизуелних снимака, јер тада одлучујући конструктивни елемент временске реорганизације пролазног друштвеног догађаја избледи. Уместо тога, замислимо неки друштвени догађај, чији снимак интерпретативна социологија користи као примарни податак, као вишегласну симфонију: у композицији су различити - и различито оркестрирани - нивои реда паралелни један са другим, од којих треба анализирати сваки појединачно (у његовом току, његовом ритму) и у њиховом међусобном односу. Последње аналитички утврдиве јединице композиције (појединачни тонови) увек се манифестују као догађај у времену. Као изоловани појединачни елементи, они имају „премало смисла сами по себи“, тј. могу се интерпретирати само у њиховом мелодијском низу. Интерпретатор као слушалац такође може да бира између два различита комплементарна интерпретативна правца: почев од појединачне симфоније (у конверзационо-аналитичком маниру), он може да пита о општим композицијским принципима који су примењени овде, као и у другим делима, или може (на објективни херменеутички начин) да се усмери на то да утврди шта чини индивидуалност и јединственост овог састава.

Не усуђујем да унапред одлучим каква корист може бити од тога да се визуелна когнитивна метафора, која је доминантна у интерпретативној социологији, замени слушном. За сада би било довољно када би ова измена утицала на то да интерпретативни социолози буду опрезнији у руковању аудиовизуелним снимцима, па би то функционисало попут налепнице упозорења на касети и видео опреми - „Министар истраживања: снимци угрожавају ваше ментално здравље“.

са немачког језика превела: Јелена Николић стручна редакција: Милош Јовановић, Јасмина Петровић и Нина Павловић 


\section{Литература}

Allert, T. (1984) „Der Familienkreis - ein Beitrag zum Verhältnis von Kultursoziologie und Familiensoziologie“, in: Soeffner, H.-G. (Hrsg.): Beiträge zu einer Soziologie der Interaktion, Frankfurt am Main, S. 53-78.

Ashmore, M., MacMillan K. \& Brown Steven D. (2004) "It's a scream. Professional hearing and tape fetishism", Journal of Pragmatics 36(3), S. 349-374.

Atkinson, J. M. (1978) Discovering suicide: Studies in the social organization of sudden death, London.

Bergmann, J. R. (1981) „Ethnomethodologische Konversationsanalyse“, in: Schröder, P. \& Steger, H. (Hrsg.) Dialogforschung. Jahrbuch 1980 des Instituts für deutsche Sprache, Düsseldorf, S. 9-51.

Bergmann, J. R. \& Srubar, I. (1985) „Die Entdeckung des Alltags - Zur Entstehung und Wirkung 'phänomenologischer' Soziologie“, in: Rehberg, K.-S. (Hrsg.) Theoriegeschichte der Soziologie, Frankfurt am Main.

Cooley, Ch. H. (1969/1928) "Case study of small institutions as a method of research", in: Cooley, Ch. H. Sociological theory and social research, New York, S. 313-322.

Dilthey, W. (1957) „Die Entstehung der Hermeneutik“, in: Dilthey, W. Gesammelte Schriften, Band 5, Stuttgart: Teubner, S. 317-338.

Douglas, J. D. (1967) The social meaning of suicide, Princeton, N.J.

Durkheim, E. (1961/1895) Die Regeln der soziologischen Methode, Neuwied.

Brand, S., Bateson, G. \& Mead, M. (1976) "For God's Sake, Margaret! Conversation with Gregory Bateson and Margaret Mead", The CoEvolution Quarterly 10, S. 32-44.

Friedrich, M., Hagemann-Doumbia, A., Kapfer, R., Peterman, W., Thoms, R. und Van der Loo, M.-J. (Hrsg.) (1984) Die Fremden sehen. Ethnologie und Film, München.

Garfinkel, H. (1967) Studies in ethnomethodology, Englewood Cliffs, N.J.

Geiger, Th. (1960) Die Gesellschaft zwischen Pathos und Nüchternheit, Kopenhagen.

Giersch, U. (1983) ,Zettels Traum. Fotokopie und vervielfältigte Kultur“،, in: Pross, H. \& Rath, C.-D. (Hrsg.) Rituale der Medienkommunikation, Berlin, S. 57-75.

Grimshaw, A. D. (Hrsg.) (1982) "Special issue on sound-image records in social interaction research", Sociological Methods \& Research 11(2), S. 115-255.

Hockings, P. (Hrsg.) (1975) Principles of visual anthropology, The Hague/Paris.

Jefferson, G. (1981) “The abominable 'Ne?': A working paper exploring the phenomenon of post-response pursuit of response", in: Occasional Paper No. 6 (University of Manchester, Department of Sociology).

Jefferson, G., Sacks, H. \&Schegloff, E. (n. d.) Notes on laughter in the pursuit of intimacy, Manuscript.

Kaplan, A. (1964) The conduct of inquiry. Methodology for behavioral science, New York.

Kisiel, Th. J. (1964) “The reality of the electron”, Philosophy Today 8, S. 56-65.

Knorr-Cetina, K. D. (1983) "The ethnographic study of scientific work: Towards a constructivist interpretation of science", in: Knorr-Cetina K.D. \& Mulkay, M. (Hrsg.) Science observed, London/Beverly Hills, S. 115-140. 
Koselleck, R. \&Stempel, W.-D. (Hrsg.) (1973) Geschichte - Ereignis und Erzählung (Poetik und Hermeneutik, Bd. 5), München.

Kracauer, S. (1971) Geschichte - vor den letzten Dingen (Schriften, Bd. 4), Frankfurt am Main.

Labov, W. \& Fanshel, D. (1977) Therapeutic discourse. Psychotherapy as conversation, New York.

Levinson, St. C. (1983) “Conversational structure”, in: Levinson, St.C. Pragmatics, Cambridge, S. 284-370.

Luckmann, Th. (1981) „Zum hermeneutischen Problem der Handlungswissenschaften“, in: Fuhrmann, M. u.a. (Hrgs.): Text und Applikation (Poetik und Hermeneutik, Bd. 9), München, S. 513-523.

Luckmann, Th. \& Bergmann, J. R. (1983) Strukturen und Funktionen von rekonstruktiven Gattungen der alltäglichen Kommunikation, DFG-Forschungsantrag, Konstanz.

Lynch, M., Livingston, E. \& Garfinkel, H. (1983) “Temporal order in laboratory work”, in: Knorr-Cetina, K. D. \& Mulkay, M. (Hrsg.) Science observed, London/Beverly Hills, S. 205-238 (deutsch in diesem Band).

Matthes, J. (1983) „Die Soziologen und ihre Zukunft“, in: Matthes, J. (Hrsg.) Krise der Arbeitsgesellschaft? Verhandlungen des 21. Deutschen Soziologentages in Bamberg 1982, Frankfurt am Main, S. 19-24.

Oevermann, U. (1983) „Zur Sache. Die Bedeutung von Adornos methodologischem Selbstverständnis für die Begründung einer materialen soziologischen Strukturanalyse“, in: Friedeburg, L.v. \& Habermas, J. (Hrsg.) Adorno-Konferenz 1983, Frankfurt am Main, S. 234-289.

Oevermann, U., Allert, T., Konau, E. \& Krambeck, J. (1979) „Die Methodologie einer 'objektiven Hermeneutik' und ihre allgemeine forschungslogische Bedeutung in den Sozialwissenschaften“, in: Soeffner, H.-G. (Hrsg.) Interpretative Verfahren in den Sozial- und Textwissenschaften, Stuttgart, S. 352-434.

Sacks, H. (1963) “Sociological description”, Berkeley Journal of Sociology. 8, S. 1-16.

Sacks, H. (1972) "An initial investigation of the usability of conversational data for doing sociology”, in: Sudnow, D. (Hrsg.) Studies in social interaction, New York, S. 31-74.

Sacks, H., Schegloff, E. \& Jefferson, G. (1974) “A simplest systematics for the organization of turn-taking for conversation", Language 50, S. 696-735.

Schegloff, E. (1968) "Sequencing in conversational openings", American Anthropologist 70, S. 1075-1095.

Schott, R. (1968) „Das Geschichtsbewußtsein schriftloser Völker“, Archiv für Begriffsgeschichte 12, S. 166-205.

Schütze, F. (1977) „Die Technik des narrativen Interviews in Interaktionsfeldstudien dargestellt an einem Projekt zur Erforschung von kommunalen Machtstrukturen“, Arbeitsberichte und Forschungsmaterialien Nr. 1 (Universität Bielefeld, Fakultät für Soziologie), Bielefeld.

Schütze, F. (1983) „Biographieforschung und narratives Interview“, Neue Praxis 13, S. 283-293.

Simmel, G. (1968/1908) Soziologie. Untersuchungen über die Formen der Vergesellschaftung, 5. Aufl., Berlin. 
Simmel, G. (1957/1916) „Das Problem der historischen Zeit“, in: Simmel, G. Brücke und Tür, Stuttgart, S. 43-58.

Smith, D. E. (1983) "No one commits suicide. Textual analylsis of ideological practices", Human Studies 6, S. 309-359.

Soeffner, H.-G. (1982) „Statt einer Einleitung: Prämissen einer sozialwissenschaftlichen Hermeneutik“, in: Soeffner, H.-G. (Hrsg.) Beiträge zu einer empirischen Sprachsoziologie, Tübingen, S. 9-48.

Wagner, J. (Hrsg.) (1979) Images of information. Still photography in the social sciences, Beverly Hills/London. 